\title{
Comprehensive Leadership Qualities of All Time Great Leader A Unique Role Model for Leaders of All Times
}

\author{
Dr.Vijetha Mukkelli \\ (Dean, School of Management Sciences, Nalla Narasimha Reddy Education Society's Group of Institutions, \\ Jawaharlal Nehru Technological University, Hyderabad, India)
}

\begin{abstract}
In this era of declining values and ethics among the leaders, there is a need to look into history to find out the leaders who relentlessly stood for values and became successful. Leadership is no more than influence. The effectiveness of this influence can be measured with the number of followers he has and the legacy he leaves behind. Without followers there is no leader. If this be true, Jesus Christ can be considered the most effective leader leaving a rich legacy behind even after 2000 years having two thirds of the world population as his followers. There have been millions and millions of people who are ready to sacrifice their lives for the sake of this all time great leader. This paper deals with the comprehensive leadership qualities of this great leader. His leadership strategies are universally applicable for all kinds of organizations. The cultivation of Christ like qualities is a demanding and relentless task of all leaders. This paper is purely qualitative and is based on literature survey.
\end{abstract}

Key words - Jesus, Leadership, Servant, Transforming, Team

\section{Introduction}

Jesus of Nazareth was the greatest leader in the history of the world [1]. How could Jesus Christ become the greatest leader? There is no other leader in the world that has as many number of followers as He has. The only definition of a leader is someone who has followers and gaining followers requires influence. Leadership is influence - nothing more, nothing less[2]. If this definition is accepted, Jesus Christ is true leader. Even after 2000 years of his resurrection, His influence on the earth has been increasing but not diminishing. As of 29 September 2009, the Earth's population was estimated by the United_States_Census_Bureau to be 6.787 billion, of which the Christian population comprises of 2.1 billion[3]. That means two thirds of the world population are the followers of Jesus Christ. Moreover it will be spread every hook and canny of the world by the time his vision is completely fulfilled. Several people attribute this success to His divine nature only. But it is not correct as he came on to the earth as fully human personality. The Scriptures are fully clear about it. Jesus was registered in the World Census taken by Caesar Augustus (Luke 2:1-6)[4] and was surnamed Christ (Mathew 1:16). Though He was God He kept aside all His privileges and came on to the earth to become fully human (Philippians 2:5-11). Becoming fully human is as true as fully being God. As an ordinary human being he experienced hunger, thirst, frustration, rejoice, tiredness, anger, trouble in spirit, betrayal etc. Because he was a human personality, he adopted different styles of leadership and strategies to accomplish his goal on the earth. Also He asked his disciples to follow the same and thereby do greater things than he did. He had never claimed that He alone could do all these things, as so many so called leaders boast about themselves. Hence, whoever follows his leadership style and strategies, can be as successful and acceptable as Jesus has been. He emphasizes his leadership philosophy by saying to his disciples, "Whosoever will be great among you, let him be your minister; and whosoever will be chief among you, let him be your servant" (Mt. 20:26-27). He introduced himself as the model and example, "I am among you as one who serves" (Luke 22:27). Servant hood means putting the lordship aside and keeping the welfare of the people and the mission of the organization above self-interest.

Absolute use of authority in many organizations has resulted in dictatorships that have tended to centralize power and render ineffective the potential of followers. In contrast, Jesus' leadership style called for leadership that balances leading in authority and serving in humility. In the new century, we need to adopt a style in which leaders lead in power and authority and yet serve with the attitude of a servant [5].

As early as 2003, several business persons, spirit-minded consultants, executives, and academics gathered at Manhattan hotel and visualized how the ideal corporate board meeting will look like in 2012. The board chairman says "May all the decisions we make today be guided by values and by love". It was the Spirit in Business World Conference sponsored by Greenfield, Massachusetts-Based Spirit in Business Inc. More than 500 business people gathered together there to affirm values rather than shareholder value as the driving force of business. Most of those values are found to have biblical roots. Regent College professor of Marketplace Theology, R. Paul Stevens called it the New Business Spirituality, while others called it New Paradigm [6]. 
The main objective of the conference is to discuss the spiritual values applicable to business. He (Sellers, February, 2003) further has summarized as follows:

Most of the Business values of this New Paradigm such as love honor; service, trust-based relationships rather than fear-based ones, cooperation, sense of achievement; competence, ethical behavior; corporate higher purpose and responsibility and personal fulfillment and development fit well into Christ's kingdom. We cannot say that these values have originated with the advent of Christ only. But most of them had found their way into the mainstream long before the New Paradigm Movement adopted by them. Participative decision-making and servant leadership models, value-driven and people-first corporate philosophies, workplace wellness programs and vision and mission statements are considered new management practices but had often found origins with biblical values [7].

As early as 1954 Drucker wrote that firms could hire only the "Whole Man" [8.] His corporate innovations nicely fit together with New Paradigm tenets as they do with biblical values that promote human dignity. "With absolute courtesy, Jesus comes to us in the workplace not to tell us what to do with our lives, but to ask what we are discovering in our search for meaning in our work," Stevens says[9]. Whenever we discuss the topic of developing leaders, the best person to begin is Jesus, Chua Wee Hian writes[10]. "No study on the theme of spiritual leadership is ever complete without a careful examination of how Jesus trained the Twelve" [11]. Then, what are the unique characteristics of Jesus Christ leadership style? His was not a single style but the interesting combination of different leadership styles. He had multiple leadership faces. He displayed various leadership faces in his three years of ministry on the earth. He was a true servant leader .At times he looked very autocratic and authoritative leader especially when he was dealing with Pharisees and Scribes. At other times, He was meek and humble. How was this possible? How could he be the authoritative as well as servant leader?

\section{Servant leadership}

The phrase "Servant Leadership" was coined by Robert K. Greenleaf [12].

The servant-leader is servant first... It begins with the natural feeling that one wants to serve, to serve first. Then conscious choice brings one to aspire to lead. That person is sharply different from one who is leader first; perhaps because of the need to assuage an unusual power drive or to acquire material possessions...The leader-first and the servant-first are two extreme types. Between them there are shadings and blends that are part of the infinite variety of human nature [13].

According to Daryl Eldridge, It is not a particular style of leadership, but rather relates to the motivation behind a leader's thoughts, words and actions [14]. Leaders can fit in any of the leadership styles; still be very much a servant leader. John 13:1-17 provides the image of servant leadership in the organization. In general a pyramid model of leadership prevails in which the leader sits atop of the rest of the group and sends orders down the chain of command. But Jesus turns that pyramid model upside down by taking up the basin and the towel to wash their feet [15]. He wants to convey his disciples that the way to be a great leader is to become the servant of all.

Jesus is the true servant leader. For this, he beautifully combined together authority and servant hood. Wisdom is a prerequisite to be a leader and obedience is to servant. He displayed both these characteristics right from his childhood. Jesus was a born leader. At the age of 12 only, he sat among the teachers in the temple at Jerusalem and conversed with them. All who heard him were astonished at his understanding and his answers (Luke 2:47). Even his parents were astonished to find their son among the scholars. When they questioned him as to why he had stayed back, he answered them that he should obey his Father's will. Later, this wise child went down to Nazareth with his parents and submitted himself to them (Luke 2:51). And he advanced in wisdom and stature and in favor with God and men (Luke 2:52). The essential requirement to be a leader is to grow in the sight of the people. This paves the way for future leadership. The same thing happened in case of Jesus

His authority was recognized even before he started his ministry. When he came to be baptized at the River Jordan, John the Baptist identified him and proclaimed that one was in their midst, the sandals on whose feet he was unworthy to tie (Mark 1:7). John was already a recognized leader having followers who revered his word (Luke 3:1-12). He introduced Jesus to crowds and asked his disciples to follow him (John 1:35-37). This made the job of Jesus very easy. They went and brought some followers to Jesus. Later Jesus himself picked some more disciples. This way he started multiplying his kingdom (organization).

The prospective leaders should learn here two lessons from Jesus. First, they should be careful about their private lives before being leaders. Second, they should be able to be honored by the existing leaders. Moreover, they should not expect that the existing leaders should come to them. Instead, they themselves should go to them. But they should be very careful in doing this. They should not go to them with a view to be identified but with a purpose. But they should be in such a comfortable position that their name was already heard to those leaders in their respective fields. Jesus went there to John with a view to be baptized. Even 
though he knew that he would be the greater leader than the John Baptist, he did not wait John to come to him; instead he himself went there. He revered John by being baptized by him, the custom introduced by this leader (no evidence for this custom in scriptures prior to John). The prospective leaders in various fields should learn giving up their ego in respecting other leaders and the customs introduced by them, however greater their vision is. Giving up ego is another important characteristic of the servant leader. It does not mean that they should not introduce any change Ken Blanchard reaffirmed the same in the following way:

What do managers need to become servant leaders? The biggest thing they need is to get their ego out of the way. Managers who somehow have themselves as the center of the universe and think everything must rotate around them are really covering up "not okay" feelings about themselves [16].

During his three year ministry, Jesus has obviously displayed the leadership and servant hood characteristics as well. He had all the marks of leadership. He attracted people to Him. When he called the people (Later the same were called disciples) to follow Him, fishermen left their nets, the tax collector left his table and others left their tasks and everything they had and followed Him. The most important characteristics of the servant are humility and sacrifice which are clearly visible in Jesus Christ.

\subsection{Humility}

Humility is the hallmark of the servant. It is incarnate meekness which a leader displays his humility by not using his authority unscrupulously. Jesus took on the very nature of a servant by turning the power-scale on its head. Explaining His humility, Leighton Ford (1993) writes, Greatness is measured by taking the last place, by a total commitment to welcome the "little ones," by a breadth of sympathy and openness to all who name his name, by a passion for personal purity, by toughness with us but gentleness with others [17].

He offered us a powerful model of servant hood. When not even one of His disciples was prepared to wash the feet of the other disciples and even of their Master's, it was Jesus, who took up the basin and towel and washed the feet of his friends [18]

Nowadays, if any meeting with CEO or any top level leader of any organization is required, prerequisite is to get a prior appointment and after getting appointment too, waiting for a long time to undergo the required procedure. But Jesus was a great exception to this. He made Himself available round the clock to all those whoever would like to meet him. He was with the people all the time. There is a famous adage that people should use their heart while judging others and brain while judging themselves. But in reality vice versa takes place. Many a times they will be kind to their own mistakes but very cruel to those of others. Once James and John came along with their mother to ask Jesus if they could sit on either side of him when He comes back with His glory (Mark 10:35). Then all other disciples began criticizing and rebuking them. Jesus did not rebuke them but explained them the requirements to become the first persons or leaders. There he emphasized the servant leadership saying- "Whoever wants to be first, must be the slave of all" (Mark 10:42-44).

The servant leader feels that once the direction is clear, his or her role is to help people achieve their goals. The servant leader seeks to help people win through teaching and coaching individuals so that they can do their best. You need to listen to your people, praise them, support them and redirect them when they deviate from their goals [19].

Jesus Christ perfectly did the same thing. He gave them the direction and they got adhered to the same till the end of their lives.

\subsection{Compassion}

Another essential characteristic to be possessed by servant leader is compassionate heart. Jesus has lots of compassion for everybody and everything. Compassion is not a symbol of weak heart. Jesus had compassion for the things as well as people. He wept over the city of Jerusalem (Luke 13:34). We find many leaders who weep for losing their positions or money. But the immense need of the hour is for those leaders who can weep for the atrocities or unlawful things taking place in their respective countries or organizations. Jesus did not stop by showing his compassion. He himself started taking remedial action as well. For this, he did not seek for the help of others. When something unlawful is found, a real leader will come forward to correct it. But before correcting his subordinates or followers, he should enjoy sufficient credibility without which the total act will become ridiculous. By the time he was cleansing the temple and sending out money exchangers only, Jesus was enjoying such a high credibility that no one could question His authority. Also the wrong doers did vacate the temple immediately without questioning his authority as if they were obeying the law and order.

There were instances where Jesus wept for personal problems of his followers as well. When his friend Lazarus was dead, He wept for His friend (John 11:35). He had compassion for the widow who lost her son (Luke 7:12 -15).The leaders who can feel and react to the problems of others will become everlasting leaders. When he found the people who were left without shepherd, he had lots of compassion for them. Especially, important leaders like Presidents, Prime Ministers and CEOs, who work hard to hire an "image 
specialist", should concentrate on learning as to how to show this kind of compassion towards all the stakeholders.. In order to show off their image, leaders like to be surrounded by press agents, body guards, loyal assistants and throngs of eager admirers. They use multiple means to gather people. Jesus was never tired of gathering multitudes. Multitudes themselves searched and followed him. They went to him wherever he was, whether it was a village or a wilderness. By looking at all this, he had never behaved like an unreachable leader but had compassion for these multitudes for not having a good shepherd. Many a times neither did he find time to eat nor to take rest, in meeting their needs and comforting them. Even when He was on cross also, he asked the women standing around him not to cry for him but for their children. Can anyone find a more compassionate leader than he on the earth?

Rev. Tony Cupit states that, leadership without compassion is barren. Jesus, a strong, bold leader, revealed a sensitivity and compassion that enhanced and balanced his strength of character and dynamic leadership [20]. He had shown compassion towards those who came to arrest him. When Peter, one of his disciples had pulled his sword and cut off the ear of the servant of the high priest, Jesus asked him not to use his sword and healed the ear of that servant, who came to arrest him (Luke 22: 51). The peak of his compassion was seen in the garden at Gethsemane. The weight of the burden or the responsibility was so high that he could no longer bear it. Even under such circumstances, he had decided to obey His Father's will remembering the lost sheep (the lost humankind). If he wanted, Jesus could have got up even at this point and walked away. But he did not do so.

Joel McClure says that servant leadership will lead us too, to make sacrifices, to put the needs of others above the direction we may prefer for ourselves [21]. Jesus had undeniable power. He could quiet an angry storm and even walk on the surface of a lake. Yet he used the power compassionately. Moreover, He had never used this power for himself but for the sake of the welfare of the others- to feed the hungry and to heal the sick etc. He wasn't concerned about a powerful image. This compassionate leader is not weak but strong as well as meek. This was revealed in his verbal expression too. People were happy to listen to his gracious words. At the same time they were amazed at his preaching with authoritative voice unlike their scribes. We can hardly find strong leaders being meek. But blessed are the meek, for they can inherit the earth (Mathew 5:5). Jesus set the example for compassionate and sacrificial leadership in his words and deeds as well. For great leaders, words and deeds will not be different but the same. This makes them exemplary leaders.

\subsection{Sacrifice}

The ultimate form of compassionate leadership is expressed in terms of sacrifices the leader makes for others. Jesus gave up glory and everything in heaven to come on to this earth. And on earth he did not withhold anything including his life. This ultimate sacrifice made him an everlasting leader of all times. The greater the sacrifice of the leader, the higher will be the number of followers who can make such sacrifices for his sake too. Tony Cupit said that, many followers of Jesus have carried their cross to Golgotha and accepted martyrdom in the name of Jesus Christ. They followed the slap of his sandals to the Cross-following the example he set [22].

If a leader is able to sacrifice his personal interests and think of organizational interest, he can find innumerable number of followers who can lay their lives for the sake of their leader and his kingdom or organization. They assist expand the organization with no boundaries in a most acceptable way. The present leaders, who measure their success in terms of the organizational expansions they make and the positions they hold, also should look back to count the unselfish sacrifices they made to achieve that success. Jesus did everything for the welfare of the people. While doing all this he did not expect anything. Even when people tried to make him a king, he departed from them silently (John 6:15); by denying this temporary position and thereby became an everlasting leader in the whole universe. Those leaders who are greedy after positions should look at Jesus and learn a lesson. They can become real heroes or leaders by sacrificing these temporary positions. Authority is entirely compatible with servant hood. Indeed ministry is itself a "servant" word. The Gospel rather suggests that authority should be exercised by servant leaders [23]. Then what is this authoritative leadership?

\section{Authoritative Leadership}

An authoritative leader is good at motivating people to do their work well. The authoritative leader helps workers understand how their jobs help the larger picture and makes sure they know what they do matters. This type of leader usually lets people do things how they want as long as the end result is acceptable [24].

When decisive action is needed, the leader should act. Jesus did the same thing. When the Temple was being used for manipulative and unscrupulous commercial interests, Jesus overturned the money changers' tables (Matthew 21:12). He did not do these things to show his power and authority but to protect the people from manipulative and unscrupulous commercial interests of money changers. He did not have any selfish interest in doing all this instead did it out of lots of passion for the temple. Hence nobody could question his 
authority. They obeyed as if they were obeying to their rulers. This way he showed his real authority and thereby proved that the authority would not be derived just from the office we hold.

In another instance, the wind and the sea obeyed him. When the howling wind and raging sea threatened to overturn the boat, the disciples got terrified. As most of the disciples were fishermen, a wind on the sea was not a new experience for them. They cried out for Jesus' help while he was sleeping without being affected. When they cried, Jesus got up and said, "Peace be still" (Mark 4:39); and a great calm came upon the sea. How many of the present leaders could come to the rescue of their followers when they were found amidst of the storms? Jesus was a strong man, a decisive leader. He confronted what was wrong or harmful and led by action. Whenever he exercised authority, he did it to help someone or to fulfill the will of his father. The common people heard Him gladly as He spoke with authority, not like the Scribes and the Pharisees (Matthew 7:29).

\section{Exemplary Leader}

Jesus set the standard by which all future leadership is to be assessed. He was the natural leader. He grew in favor with God and men. He submitted Himself to his parents (Luke 2:51-52). How many leaders have good testimonies about their childhood? At the age of twelve only, the wise men were amazed at his wisdom. When he came on to ministry, He did not raise his voice to be heard. He didn't need to strike the synagogue pulpit to be heard. Instead people crowded him to hear God's message (Luke 5:1). He was a born leader. By being very much impressed with his words and deeds, people tried to make him a king. As Jesus realized that they would try to force him to be their king, he went upon a mountain, where he could be alone (John 6:15).

Followers mirror their leaders literally. Perhaps the most stunning discovery in behavioural neuroscience is the identification of mirror neurons in widely dispersed areas of the brain..........Collectively these neurons create an instant sense of shared experience. Mirror neurons have particular importance in organizations because leaders' emotions and actions prompt followers to mirror those feelings and deeds. The effects of activating neural circuitry in followers' brains can be very powerful.[25]

The leaders who work for titles and positions should learn a lot from this great leader. Moreover, several leaders are recognized and remembered for their positions and designations but not for their power. Power is the ability to influence others. Once they lose their positions, they will not be remembered any longer. For this reason, they want to continue in authority at any cost. But Jesus is remembered for his power but not for official position. In fact, he denied all the positions and declared that the Son of Man has come to serve but not to be served. Even Pilate wanted Jesus to accept the designation of King of the Jews. But he denied the worldly titles. He needed no human title to establish his leadership. Leadership was inherent quality for Him. This is how he sets an example of strong and sensitive leadership for all who would like to assume leadership position.

\section{Guiding Leader}

Jesus was not just a teacher to his disciples, but was a role model, guide, philosopher and everything for his disciples. Once he asked his disciples whether they would leave him too. Then, Peter immediately responded that they would not find this kind of living words elsewhere, so they would never cease following. He was a good teacher as well as excellent communicator. He adopted two way communication techniques which are considered most powerful communication techniques of the 21 century. Even in twenty first century, several leaders want their followers to listen to and obey their orders. They don't allow others to speak much. His teaching was not confined to narration of subjects to a passive group of disciples who were at the receiving end. Instead, dialogue method was adopted by Jesus. Every session was open to questions. While teaching, he made the disciples think, encouraged them to meditate over issues until they came to the understanding. Through debates, he exposed the common myths of the day. Jesus not only shared knowledge but also shared all his experiences. They together faced the problems of life and ministry. In all times of embarrassing and exhilarating, Jesus was with them and helped them think with a clear and critical mind.

The only way to develop your social circuitry effectively is to undertake the hard work of changing behaviour. Companies interested in leadership development need to being by assessing the willingness of individuals to enter a change program..... the aspiring leaders can be trained in specific areas where developing better social skills will have the greatest payoff. The training can range from rehearsing better ways of interacting and trying them out at every opportunity, to being shadowed by a coach and then debriefed about what he observes, to learning effectively from a role model. The options are many but a road to success is always tough [26].

How many present leaders guide their subordinates or followers like this? Several leaders entrust responsibility without giving guidelines to discharge that responsibility. Not only did Jesus give guidelines but also delegated required authority to complete the task. 


\section{Delegating Leader}

Whenever he felt feasible, he delegated the things to his disciples. He gave them practical problems and asked them to think over solutions. Many companies grandly proclaim "People are our greatest asset ", only to watch most of them show little true commitment to developing and leveraging those people's abilities [27]. If we consider the case of Philip, Christ gave him a problem concerned to the feeding of the five thousand. Jesus has done this to test him (John 6:6). Otherwise, he may not have understood completely what Jesus wanted him to learn. A part of His assignments were 'unglamorous' too and the same were expected to be performed in public place. In the above mentioned incident of feeding five thousand, He called his disciples to help seat the crowd and to clean up the place after the crowd had eaten. Then he commanded them to make them all sit down in groups on the green grass. And they took up twelve baskets full of fragments and of the fish. (Mark 6:40, 43). The leader should be able to make them feel that every work is important and no work to be considered mean. This kind of training is essential in this era of full of status conscious and egotism. There are many leaders who confine others to perform insignificant assignments only. But Jesus did not do so. He delegated them very complex and significant assignments too.

On another occasion Jesus sent them out on a restricted mission trip (Matthew 10). While sending them, He gave the required instructions and guidelines. He made them clear about their target, their travel plan, the likely problems and rejections they would come across in their ministry, in such case, the kind of help that was available etc. Keeping all these clear instructions in mind, they successfully completed the given assignment and reported back to their Master. Jesus heard them carefully when they were narrating their experiences. Later he asked them to take rest for a while as they were found tired of their travel. Entrusting Practical assignments is important for leaders in training for they learn best while being on the job.

Assigning a job itself is not sufficient, their performance to be reviewed and due appreciation and recognition to be extended for all their achievements. Then only they will be motivated to work further. Beginning with controlled situations, Jesus gradually exposed his disciples to various stages of responsibility. Step-by-step delegation can be a very useful tool in molding good and practical leaders who are able to do the job and does it well. Similarly, while sending them on an assignment, trainee leaders should be provided with clear and simple instructions. If clear instructions are not there, there is every possibility that they may fail in discharging their responsibilities. There has to be sufficient orientation to the task. Clear instructions simply presented and the provisions of a companion are the reasons for their successful completion of tasks assigned to them [28].

\section{Transformational Leader}

Everyone who encountered Jesus was transformed. No one was the same after meeting Jesus. Why? This question was posed by Laurie Beth Jones, author of "Jesus, CEO" and "Jesus, Entrepreneur," while she was the guest speaker at the Concordia University Christian Leadership Series Luncheon on Wednesday, Feb. 1, 2006 in Newport Beach, Calif. According to the Director of the University Communication, Doug Fleischli, the gathering boasted a record high attendance of more than 470 business men and women of southern California. During the luncheon, attendees were called to study the life of Jesus and apply his leadership skills into their own businesses [29].

Now, the answer to the question is - He is a true transformational leader. People who encountered him were also transformed. Transformational leader is one who can motivate people by using energy, enthusiasm, and passion to sell a vision[30]." According to Burns, the transformational style creates significant change in the life of people and organizations. It redesigns perceptions and values, changes expectations and aspirations of people." [31] This is possible through modeling. In his gospel, Mark begins telling how Jesus went to be baptized by John in the Jordan. As Jesus was coming up out of the water, he saw heaven being torn open and the Spirit descending on him like a dove. A voice came from heaven: 'You are my Son, whom I love; with you I am well pleased"(Mathew 3:16-17).Father told Jesus he was well pleased with him before Jesus had done anything, said anything, healed anybody, taught anyone. The Father was pleased with him for what he was. Jesus' leadership began not first with doing, but with being. As a Transformational leader, he displayed his transformational characteristics of transformational vision, transformational empowerment and finally adopted the method of telling transformational stories to transform them.

\subsection{Transforming vision}

He visualized the kingdom without boundaries. Right from the beginning of picking up the disciples, he was continuously working for this only. He was searching for suitable people who could work on this till end. Immediately after his baptism, Jesus "saw" Simon and Andrew and called them to follow him. A little farther, "he saw" James and his brother, John. And he called them. Still later "he saw" Levi or Matthew at his tax collector's booth and called him to follow. There is something special in his "seeing". Jesus was the Seer who "saw" the eternal in everybody he was choosing. Through His eternal outlook, He was able to assess their 
strengths and weaknesses and to what extent they would be useful for the expansion of His kingdom. For Jesus, vision was not an entrepreneurial program His vision was not that of dreams in the sky, but the kingdom at the next corner. He chose only those who could stay with Him till the end. When some people wanted to follow Him, He denied, saying that everything has place on the earth but the son of man has no place to rest. It was the vision of seeing what lost and wayward people could become only prompted Him to choose the right persons. Out of that vision sprang his mission to seek and find the lost. He said that his kingdom would have no geographical boundaries. He was very practical in making this statement. This statement of vision has been fulfilled now. So the second mark of the transforming leadership is the ability to see and to translate that vision into action.

A true transformational leader should visualize the "Ultimate" in the beginning itself. Action plan to be developed to achieve this ultimate. Many leaders have visions. But many a times they are not much careful in developing clear plans and choosing right people to accomplish that. Because of this reason, many leadership partnerships will not last for a long time. But a true transformational leader will be very careful in making the relationships everlasting. Not only Jesus was expert in seeing through the personalities of the people, but also was successful in communicating His vision to the chosen. Interestingly he has chosen the method of storytelling to communicate his vision and ideas.

\subsection{Transforming stories}

Jesus was also the Storyteller who communicated his vision by the stories he told. "He taught them many things by parables," Mark recalls in Mark 4:2. It was written that he had taught them nothing without a story. Once The President of The Center for Creative Leadership in North Carolina, an outstanding center for the study and teaching of leadership, said that they have examined the different ways in which organizations and businesses try to instill values - putting them into slogans, giving a list of rules, putting their essential values onto posters, but their research shows that nothing works like the telling of a values story, a "parable" which tells how someone in that company or organization acted on their values. Though it is a costly way, they made a difference. Those stories helped values to be passed on[32.]This may be a new insight to this twenty first century CEO, but not to Jesus Christ and His followers of the first century. Jesus had shown many centuries before that the stories could be like time bombs exploding his transforming power in people's minds and hearts. If every transforming leader learns to pass on their vision through stories, the vision of the leader can be impressed upon the minds of the followers.

\subsection{Transforming Empowerment}

Everyone knows about Jesus that he is the Good Shepherd, seeking the lost sheep. But many a time people ignore the fact that he is an ideal Shepherd Maker too. He had equal concern for winning the "lost sheep", and to transform them into "good shepherds". A good shepherd is one who can lay his life for his sheep. Jesus became good shepherd by laying his life for the sake of the entire lost sheep or humankind. Not only did He lay His life but also prepared his followers to do this.

Modeling is essential characteristic of true transformational leader. So the bottom line for Jesus was not just getting the job done, but building people and getting the job done. For this, he has chosen the twelve and called them 'Apostles'. He has chosen them to spend with them, to teach them, to test them, to challenge them, to motivate them, to correct them and finally to empower them as his equals. Hence, in John the Gospel He told them that he would no longer call them servants but friends - a true characteristic of transformational leader. He came on to the earth to transform people but not just to develop procedures and programmes. He put his mind in people but not on papers or on emphasizing rules and regulations. And so was Jesus marked and so should every transforming leader be marked not just by open hands, but by laid on hands, hands laid on the heads of others to empower [33].

Leadership specialist, Warren Benniss, concluded after interviewing 90 leaders in many fields that transforming leaders operate through four strategies. They are - grabbing Vision, establishing meaning for vision, finding imaginative ways to communicate vision to their followers and finally establishing trust through positioning[34]. The followers of the transformational leader will understand that they will have to pass this vision on to others who will team with, complement and support them. But Benniss's strategies are not strange to the world. In fact, they are embodied perfectly in the transforming leadership of Jesus Christ. Those leaders, who would like to expand their organizations without frontiers, should learn to apply the transformational leadership concept of Jesus Christ.

\section{Listening Leader}

Jesus listened to carefully those who like him as well as who don't like him. He listened to the problems of the needy; listened and clarified the doubts of the disciples and listened to the Pharisees and scribes who always try to find fault with his preaching. Above all He listened to His archenemy Satan, whose 
sole objective is to destroy the constructive work of Lord Jesus Christ. When the destroyer (Satan) came to test Him, He listened to Him patiently and answered all his arguments. When Satan cited Scriptures to defeat Him, Jesus reiterated His words using the same Scriptures. While retarding, He was so rational in His approach that Satan himself ran away from him without being able to answer. How many of the present generation leaders can be like Jesus Christ while they are dealing with their adversaries or competitors?

Similarly, He had perspective about problems and people. He knew 2,000 years ago the effect and impact of his teachings, not only on those who were to hear them at the moment, but also on the people who read them today. For this reason he used to approach every problem in such a way that it can be universally applicable without place and time boundaries. So often, leaders of today rush in to solve problems by seeking to stop the present pain only. They do what they perceive as popular and thereby create even greater difficulty and pain later on.

\section{Practical Leader}

There is a popular saying that the first responsibility of a leader is to define reality and the last is to say thank you. In between, the leader has to be a servant. If this is true, Jesus is perfect practical leader. He has never tried to conceal the difficulties people would come across following him. But amidst of all these difficulties and persecutions, He gave blessed assurance of the seven fold blessings they would receive in future. In doing all these things, he has never behaved like a dictator or boss, but a perfect servant. All of this might sound arrogant to a generation that places higher esteem to personal knowledge than to external guidance. The structures and institutions such as the family, schools and religion that have traditionally provided us with external guidance are dissolving; the belief that individuals are their own best source of wisdom is growing strong and strong every day. Theoretically, it makes sense. But, in reality it has never worked in any sustainable way. Also human studies have shown that all people take their cues not from the realities of the environment, but from their own biases, desires, perceptions and distractions. This was absolutely true in all times especially in time of Jesus. Scribes and Pharisees were busy with interpreting the laws and thereby distracting the essence of law i.e. humanity and kindness. Most important function of leadership then is to help followers create a more accurate and constructive view of reality. Jesus did the same thing.

True leadership should not to be confused with dictatorship. At the same time, it does not take away an individual's freedom, choice, accountability or responsibility. He gave ample freedom to his disciples to ask questions and make queries about anything and their ideas were taken into account. In doing so, they, along with the leader, practiced self-restraint, developed character; integrated discipline and practiced love and respect for other people. This gave an opportunity to create a kind of self-leadership at all levels of the group. This kind of leadership promotes a kind of self-leadership environment where all are empowered to work towards the good of the whole in the best interest of all. Jesus while giving a call to follow him also explained the persecutions that they will come across in ministry. He attracted them by not giving the rosy picture but making them properly understand the fruits of the persecution. This understanding made them sacrifice their lives too for the task they were entrusted with. Jesus was always practical and honest. While sending the enlisted disciples on mission, he gave those instructions and guidelines (Mathew 10: 5-15). At the same he warned of the troubles involved in the practical ministry. He advised them to be as wise as snakes as innocent as doves. By that time they mentally became so strong that they didn't drive back, despite knowing all the troubles associated.

\section{Team Leader}

Jesus was a great team leader. He personally enlisted his team. He said, "Come, follow me." Personal enlistment is always the most powerful way to gather a team. While He was sending them for practical ministry, He sent them in teams, each team consisting of the two. The team will be powerful, if the enlistment of teams is made directly by the leader himself. Jesus believes in team leadership. Whenever Jesus sent out his disciples on a practical mission, he never sent them out alone. A fellow disciple who would provide companionship and support was always provided. He sent them out two by two (Mark 6:7) - so should we do with our trainee leaders.

\section{Stewardship Leader}

It is a well-worn word, but one that lacks weight in our culture. Perhaps a substitute term used at present is trustee. When Jesus restored Peter and asked him, "Peter, do you love me?" Jesus told Peter to take care of his lambs. Aspiring to be a leader is not something to be entered into without counting the cost. Jesus cited one parable to make us understand the image of the Trustee. In the Parable of the Talents, three servants were entrusted with various amounts of money. The first two servants were good and faithful and invested what they had been given and doubled their investment. The last was wicked who did nothing but buried his trust 
(talent) in the ground. The master returned and rewarded the two who had been faithful in his absence as they would have acted had he been there. The master was upset with the last one as he did not act responsibly with the talents he was entrusted with. Faithfulness is the hallmark of the leader as a trustee. As leaders, our responsibility lies in the relationships and vocations we have been given. Jesus was entrusted with a mission and a group of disciples. He was faithful in obedience to his mission and in his development of his disciple [35].

\section{Conclusion}

In this era of declining values and ethics among the leaders, there is a need to look into history to find out the leaders who relentlessly stood for values and became successful. The cultivation of Christ like qualities is a demanding and relentless task. Perfection is achieved by abolishing weakness. A famous sculptor once said that there was nothing in his art except just cutting away the marble that he didn't want there. And so there's nothing to attaining perfection either, except one by one, removing all the obstacles and the obstructions that pollute it[36]. If we look at the present leaders in any field, we find examples of leaders abandoning values, manipulating power, betraying trust, exploiting privileges of position, bringing ruin to trusted followers, preferring personal interests to general interests etc. The good news is that there is a better way. There is one perfect leadership role model that we can trust, and His name is Jesus. They can attain perfection by removing these obstacles and obstructions that pollute their leadership styles and strategies, by comparing their leadership styles with perfect leadership style of Jesus Christ. If they cut these imperfections once, they will become perfect and there by become as successful and acceptable as Jesus Christ. "Aspiring to be like Jesus is not a matter of status or a spiritual ascent; it's a journey, a destination, a joyous arriving. It was what we were made to be like from all eternity" [37].

\section{References}

[1]. Joel McClure. Leading like Jesus: Five Metaphors for Christ like Leadership, from reading room @ water's edge. Retrieved from http://www.watersedge.tv/leadinglikejesus.htm.

[2]. John C. Maxwell (1998), The 21 Irrefutable Laws of Leadership, Thomas Nelson Publishers.

[3]. World Population, (9 September 2009) In Wikipedia, the Free Encyclopedia Retrieved from http://en.wikipedia.org/wiki/World_population

[4]. All Scripture citations will be in the New International Version (NIV), unless otherwise stated.

[5]. Jeff.M.Sellers (February, 2003). The Higher Self Gets Down to Business. Christianity Today 47 (2). Retrieved from http://www.christianitytoday.com/ct/2003/february/1.34.html

[6]. Jeff.M.Sellers (February, 2003). The Higher Self Gets Down to Business. Christianity Today 47 (2). Retrieved from http://www.christianitytoday.com/ct/2003/february/1.34.html

[7]. Jeff.M.Sellers (February, 2003). The Higher Self Gets Down to Business. Christianity Today 47 (2). Retrieved from http://www.christianitytoday.com/ct/2003/february/1.34.html

[8]. Drucker Peter F(1954). The Practice of Management. HarperCollins Publishers

[9]. Jeff.M.Sellers (February, 2003). The Higher Self Gets Down to Business. Christianity Today 47 (2). Retrieved from http://www.christianitytoday.com/ct/2003/february/1.34.html

[10]. Chua Wee Hian (1987). Learning to Lead. Inter-Varsity Press. Retrieved from http://jmm.aaa.net.au/articles/8742.htm

[11]. Chua Wee Hian (1987). Learning to Lead. Inter-Varsity Press. Retrieved from http://jmm.aaa.net.au/articles/8742.htm

[12]. http://www.greenleaf.org/whatissl/ servant leadership

[13]. http://www.greenleaf.org/whatissl/ servant leadership

[14]. Daryl Eldridge (October 2002). Leadership Development, the Jesus Way. The Sunday School Leader, pp. 10-12.

[15]. Rev. Tony Cupit (Baptist World Alliance), Jesus: Servant Leader, John Mark Ministries website (http://jmm.aaa.net.au/articles/8742.htm

[16]. Ken Blanchard. Servant Leadership- condensed from The Blanchard Management Report. Positive Living March/April 1999. Retrieved from http://www.appleseeds.org/Blanchard_Serv-Lead.htm

[17]. Leighton Ford. Transforming Leadership: Jesus' Way Of Creating Vision, Shaping Values \& Empowering Change, Intervarsity Press, 1993. Retrieved from http://www.watersedge.tv/leadinglikejesus.htm

[18]. Joel McClure. Leading like Jesus: Five Metaphors for Christ like Leadership, from reading room @ water's edge. Retrieved from http://www.watersedge.tv/leadinglikejesus.htm.

[19]. Kenneth Blanchard \& Phil Hodges (2005) Lead Like Jesus http://www.amazon.com/Lead-Like-Jesus-GreatestLeadership/dp/0849918723/ref=reader_auth_dp\#reader

[20]. Kenneth Blanchard \& Phil Hodges (2005) Lead Like Jesus http://www.amazon.com/Lead-Like-Jesus-GreatestLeadership/dp/0849918723/ref=reader auth dp\#reader

[21]. Joel McClure. Leading like Jesus: Five Metaphors for Christ like Leadership, from reading room @ water's edge. Retrieved from http://www.watersedge.tv/leadinglikejesus.htm.

[22]. Rev. Tony Cupit (Baptist World Alliance), Jesus: Servant Leader, John Mark Ministries website (http://jmm.aaa.net.au/articles/8742.htm

[23]. John Piper, "Barnabas, The Maker of Great Leader", www.desiringgod.org, July 12, 1987.

[24]. Goleman D(2000), "Leadership that gets results", Harvard Business Review, March-April, pp 78-90

[25]. Daniel Goleman and Richard Boyatzis, "Social Intelligence and the Biology of Leadership", Harward Business Review , September 2008, pp 2-5

[26]. Daniel Goleman and Richard Boyatzis, "Social Intelligence and the Biology of Leadership", Harward Business Review , September 2008, pp 2-5 
[27]. Matthew D. Breitfelder and Daisy Wademan Dowling, “Why Did We Ever Go Into HR?”, Harvard Business Review July-August 2008

[28]. Rev. Tony Cupit (Baptist World Alliance), Jesus: Servant Leader, John Mark Ministries website (http://jmm.aaa.net.au/articles/8742.htm

[29]. Michelle Vu. (2006, July 5). Jesus CEO Author Uses Christ as Business Leadership Model. The Christian Post

[30]. Transformational leadership (2009) In The American Heritage Dictionary of Business Terms Retrieved September 15th, 2009, from www.yourdictionary.com/business/transformational-leadership)

[31]. Transformational leadership,( September 2006) In Wikipedia, the Free Encyclopedia Retrieved from http://en.wikipedia.org/wiki/Transformational_leadership

[32]. Vijetha Mukkelli, "Leadership Thought in the Bible in the Bible and Its Relevance to the Present Scenario with Special Emphasis on Corporate Sector" (PhD diss., Osmania University ,2008).

[33]. Ford, "Jesus as a Model for Leaders", Gospelcom.net.

[34]. Vijetha Mukkelli, "Leadership Thought in the Bible in the Bible and Its Relevance to the Present Scenario with Special Emphasis on Corporate Sector" (PhD diss., Osmania University , 2008).

[35]. Joel McClure. Leading Like Jesus: Five Metaphors for Christ like Leadership, from reading room @ water's edge 